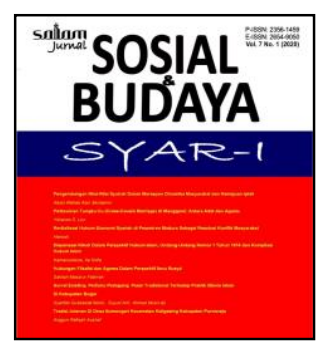

P-ISSN: 2356-1459. E-ISSN: 2654-9050

Vol. 8 No. 1 (2021), pp. 89-108

DOI: 10.15408/sjsbs.v8i1.19079

http://journal.uinjkt.ac.id/index.php/salam/index

\title{
Computer-Mediated Communication dan Manajemen Kesan Pada Pembelajaran Elektronik Mahasiswa Di Masa Pandemi Covid-19*
}

\author{
Atika Suri' ${ }^{1}$, Firda Ayu Kusuma Dewi Subagyo², Irwansyah ${ }^{3}$ \\ Program Pasca Sarjana Jurusan Komunikasi FISIP UI
}

$\underline{10.15408 / \text { sjsbs.v8i1.19079 }}$

\begin{abstract}
Computers have become an inseparable part of everyday life. Moreover, with the introduction of the internet, computers in various forms are now a means of finding information and communicating effectively, quickly, and reliably. In its development, the internet opens up the possibility of electronic learning or e-learning, which is currently developing online learning. Electronic learning allows direct and two-way interaction between teacher-students as well as fellow students mediated by the Computer. All forms of communication that are mediated by digital or computer technology are known as ComputerMediated Communication, where the human communication process through computers is not seen from a technical point of view, but how communication is carried out that involves many people in certain contexts for various purposes. Besides, in the era of the Covid-19 pandemic, e-learning is the only learning pattern suitable for use when direct interaction between individuals is limited. This study looks further at the computer-mediated communication process in the implementation of education. The results of qualitative research with an interview approach show that each student has their way of presenting themselves and building impressions in class during online lectures. The hyperpersonal communication pattern is carried out by students during lectures, by displaying a serious selfimage and listening to the lecturer. This self-image is formed by selecting and determining what responses should be displayed in certain classroom conditions. The process of forming this self-image can then be said to be a form of student impression management in online lecture forums.
\end{abstract}

Keyword: Computer-Mediated Communication; Impression Management; Covid-19; Electronic Learning

\begin{abstract}
Abstrak
Komputer telah menjadi bagian yang tidak terpisahkan dari kehidupan sehari-hari. Apalagi dengan diperkenalkannya internet, komputer dalam berbagai bentuk saat ini menjadi sarana mencari informasi dan berkomunikasi yang efektif, cepat dan andal. Dalam perkembangannya internet membuka kemungkinan dilakukannya pembelajaran elektronik atau e-learning yang perkembangannya saat ini menjadi pembelajaran online. Pembelajaran
\end{abstract}

${ }^{*}$ Received: December 05, 2020, Revision: December 15, 2020, Published: January 23, 2021.

${ }^{1}$ Atika Suri adalah mahasiswa pascasarjana pada Departemen Ilmu Komunikasi, Fakultas Ilmu Sosial dan Politik, Universitas Indonesia

${ }^{2}$ Firda Ayu Kusuma Dewi Subagyo adalah mahasiswa pascasarjana pada Departemen Ilmu Komunikasi, Fakultas Ilmu Sosial dan Politik, Universitas Indonesia

${ }^{3}$ Irwansyah adalah dosen pengajar pascasarjana pada Departemen Ilmu Komunikasi, Fakultas Ilmu Sosial dan Politik, Universitas Indonesia 
elektronik memungkinkan interaksi langsung dan dua arah antara guru-murid termasuk juga sesama murid yang dimediasi oleh Komputer. Segala bentuk komunikasi yang dimediasi oleh teknologi digital atau komputer dikenal sebagai Computer-Mediated Communication, dimana proses komunikasi manusia melalui komputer tidak dilihat dari sisi teknis, namun bagaimana komunikasi yang dilakukan yang melibatkan banyak orang dalam konteks tertentu untuk berbagai keperluan. Terlebih lagi di era pandemi Covid-19, e-learning menjadi satu-satunya pola pembelajaran yang cocok digunakan disaat interaksi langsung antar individu dibatasi. Penelitian ini melihat lebih jauh proses komunikasi yang dimediasi komputer dalam pelaksanaan pendidikan. Hasil penelitian kualitatif dengan pendekatan wawancara menunjukkan bahwa setiap mahasiswa memiliki caranya masing-masing untuk menampilkan dirinya dan membangun kesan di kelas selama perkuliahan online berlangsung. Pola komunikasi hyperpersonal ini dilakukan oleh mahasiswa selama perkuliahan dengan menampilkan gambaran diri yang serius dan menyimak materi perkuliahan yang disampaikan oleh dosen. Gambaran diri ini dibentuk dengan menyeleksi dan menentukan respon apa yang harus ditampilkan dalam kondisi suasana kelas tertentu. Proses membentuk gambaran diri ini kemudian dapat dikatakan sebagai bentuk dari manajemen impresi mahasiswa dalam forum perkuliahan online.

Kata kunci: Computer Mediated Communication; Manajemen Impresi; Covid-19; Pembelajaran Elektronik

\section{A. PENDAHULUAN}

Di masa pandemi Covid 19 pembelajaran elektronik atau e-learning menggantikan pola pembelajaran tradisional yang mengharuskan siswa dan guru menjalankan proses tatap muka. Pembelajaran elektronik bisa membantu berlanjutnya proses belajar mengajar sekaligus mengakomodir anjuran pemerintah untuk mengurangi interaksi langsung dalam rangka menekan penyebaran virus Covid 19. Pola pembelajaran elektronik tidak hanya untuk komunikasi satu arah, tetapi memungkinkan pula komunikasi antara guru dan siswa serta komunikasi antar siswa dalam bentuk dalam jaringan (daring) atau online. Hal ini menunjukan bahwa pembelajaran seperti ini memiliki kelebihan dan dapat digunakan secara efektif tidak hanya dari sisi jarak tetapi juga untuk tatap muka dalam bidang pendidikan. ${ }^{4}$

Dalam perkembangannya pembelajaran elektronik digunakan dalam berbagai bidang ilmu. Di Taiwan, pembelajaran elektronik digunakan oleh para mahasiswa dalam konteks pembelajaran bahasa Inggris sebagai bahasa asing di negara tersebut. Para mahasiswa bisa langsung berkomunikasi tidak hanya di dalam namun juga di luar kelas dimediasi perangkat komputer dengan terlebih dahulu mengunduh program skype untuk berkomunikasi langsung dan surat elektronik atau email untuk komunikasi menggunakan teks. Kegiatan ini melibatkan mahasiswa dalam proyek antar budaya dengan mahasiswa dari Amerika Serikat. Hasil penelitian mendapati, para siswa awalnya mendapati banyak tekanan, tidak hanya masalah teknis, namun juga non teknis untuk berkomunikasi dengan bahasa asing. Namun pada akhirnya para siswa memiliki pengalaman baru pembelajaran elektronik yang dimediasi komputer bahkan dilakukan

${ }^{4}$ Hubackova, Sarka (2015). History And Perspectives Of Elearning Procedia - Social and Behavioral Sciences 191, $1187-1188$ 
antara budaya dengan penutur asli bahasa Inggris. ${ }^{5}$ Penelitian ini berfokus membahas komunikasi interpersonal. Pola komunikasi hyperpersonal dalam interaksi yang termediasi komputer tidak dibahas dalam jurnal ini.

Tantangan pembelajaran elektronik bagi mahasiswa dan guru memang berbeda dengan pembelajaran tradisional atau tatap muka. Di Kenya, Afrika, penelitian yang dilakukan di dua perguruan tinggi setempat menyandingkan dua teori yakni Computer Mediated Communication (CMC) dengan teori identitas Sosial atau Social Identity yang disingkat SIDE. Teori Identitas Sosial ini banyak digunakan dalam bidang psikologi sosial untuk menjelaskan perilaku dalam kelompok. Keduanya disandingkan untuk melihat bagaimana siswa dan pengajar beradaptasi dengan E-Learning untuk meningkatkan potensi akademik dalam pola pembelajaran elektronik. ${ }^{6}$ Penelitian ini fokus pada pengembangan komunikasi interpersonal dengan pendekatan teori Identitas Sosial dan tidak membahas lebih jauh tentang pola komunikasi hyperpersonal.

Pada penelitian lainnya di Jepang, terdapat penelitian yang menyandingkan pola Computer Mediated Communication dengan teori kehadiran sosial. Dalam pembelajaran Virtual kehadiran guru dan teman tidak lagi sama ketika pembelajaran dilakukan secara tatap muka langsung. Kondisi ini ternyata menguntungkan siswa yang senang bekerja individual. Oleh karena itu perlu peran penting guru untuk meningkatkan keterampilan siswa dalam interaksi online dalam pembelajaran yang mendukung komunitas. ${ }^{7}$ Penelitian ini fokus membahas pola komunikasi interpersonal yang terjadi dalam kelas online dan dikaitkan dengan teori Kehadiran Sosial. Pola komunikasi hiperpersonal tidak diungkit dalam penelitian ini.

Di Tennessee, Amerika Serikat, pola pembelajaran elektronik diberikan untuk perbaikan tugas Matematika, yang kerap menjadi hambatan utama bagi kelulusan siswa. Pengiriman soal remedial melalui jaringan komputer memungkinkan siswa mempercepat pengerjaan dan siap melanjutkan proses perkuliahan. Konsep ini juga diterapkan sebagai kursus di kalangan mahasiswa dan siswa SMA. Penelitian dilakukan untuk melihat implementasi dan keberhasilan pembelajaran matematika yang dimediasi Komputer. Penelitian ini juga membuktikan bahwa siswa ternyata mampu belajar mandiri meski tidak berada di ruang kelas. ${ }^{8}$ Penelitian ini membahas pola komunikasi impersonal dan interpersonal, sedangkan komunikasi hiperpersonal yang terjadi dalam pembelajaran online tidak diungkap pada penelitian ini.

Di Indonesia, pandemi Covid 19 mengharuskan pemerintah menerapkan Pembatasan Sosial Berskala Besar (PSBB) untuk mengatur berbagai aktivitas, termasuk

${ }^{5} \mathrm{Hsu}$, Stella \& Beasly, Robert (2019). The Effects of International Email and Skype Interactions on Computer-Mediated Communication Perceptions and Attitudes and Intercultural Competence in Taiwanese Students

${ }^{6}$ Radoli, Lydia Ouma (2020). Switching to SIDE Mode"- COVID-19 and the Adaptation of Computer Mediated Communication Learning in Kenya Kenya:RAIS

${ }^{7}$ Kano, Masayo (2020), Maintaining and Enhancing Students' Collaborative Learning in a Japanese EFL Higher Education Context Japan: JEICOM

8 Fay, Maggie (2017). Computer-Mediated Developmental Math Courses in Tennessee High Schoolsand Community Colleges: An Exploration of the Consequences of Institutional Context Community College Research Center, USA 
di bidang pendidikan. Pemerintah melalui Keputusan Menteri Pendidikan dan Kebudayaan nomor 4 tahun 2020 dan diperkuat oleh Keputusan Menteri Pendidikan dan Kebudayaan nomor 15 tahun 2020 dan ditegaskan dalam Pedoman Penyelenggaraan Belajar dari Rumah menegaskan, bahwa proses belajar mengajar terkait penyebaran Coronavirus Disease (Covid 19) dilakukan di rumah melalui pembelajaran elektronik atau e-learning yang meliputi pembelajaran luar jaringan (luring) atau offline atau pembelajaran dalam jaringan (daring) atau online sesuai kemampuan daerah masing-masing. ${ }^{9}$ Kondisi ini bukan kendala bagi Kampus yang sudah memiliki sistem akademik berbasis online, namun ini menjadi tantangan bagi banyak kampus di Indonesia yang belum memiliki fasilitas akademik berbasis online. Sebuah penelitian lain di Indonesia mengemukakan bahwa terdapat tantangan baru yang dihadapi siswa dan pengajar yang selama ini terbiasa dengan pembelajaran tatap muka. Jalur internet yang kurang stabil di lokasi pengajar dan siswa kerap menjadi kendala dalam menerapkan pembelajaran elektronik. Saat ini sudah ada beberapa aplikasi pembelajaran elektronik gratis untuk mahasiswa seperti: Google Classroom, Kelas Kita, Sekolah Mu, Edmodo dan Schoology. Sayangnya upaya semacam ini tidak akan banyak membantu jika kendala-kendala teknis yang menjadi dasar pembelajaran elektronik tidak juga bisa diatasi. ${ }^{10}$ Penelitian ini membahas pola komunikasi interpersonal yang terjadi dalam pembelajaran online. Pola komunikasi hyperpersonal yang terjadi dalam pembelajaran online belum terungkap pada penelitian ini.

Sebagian besar penelitian diatas dilakukan untuk melihat bagaimana pola komunikasi interpersonal yang dimediasi komputer terkait kelangsungan proses penerimaan materi dan pada akhirnya mendapat hasil sesuai dengan target pembelajaran. Fokus penelitian yang ada sebelumnya yakni untuk melihat keberhasilan penyerapan materi belajar mahasiswa yang baru mulai mempraktekan Pembelajaran Jarak Jauh dengan berbagai kendala teknis dan non-teknis yang harus dihadapi untuk bisa menerima materi pembelajaran. Di Indonesia hampir satu tahun sudah Pembelajaran Jarak Jauh dilakukan. Sebagian besar mahasiswa sudah beradaptasi dengan hal teknis dan mampu menyerap materi pembelajaran. Saat hal yang mendasar dalam pembelajaran sudah berjalan, layaknya dalam kelas tatap muka mahasiswa juga perlu melakukan pengelolaan kesan atau manajemen impresi, naluri yang dimiliki setiap orang agar sosoknya bisa diterima dalam kelompok. ${ }^{11}$ Manajemen kesan diperlukan agar mahasiswa bisa mendapatkan nilai tambah dalam berbagai situasi termasuk dalam pembelajaran. Penelitian ini akan melihat apakah mahasiswa bisa menerapkan manajemen kesan melalui model Hyperpersonal dalam CMC dalam kegiatan perkuliahan?

\footnotetext{
https://www.kemdikbud.go.id/main/blog/2020/03/mendikbud-terbitkan-se-tentangpelaksanaan-pendidikan-dalam-masa-darurat-covid19

10 Zaharah, et al (2020). Impact of Corona Virus Outbreak Towards Teaching and Learning Activities in Indonesia Salam Jurnal, Jakarta

${ }^{11}$ Goffman, Erving (1969). The Presentation of Self in Everyday Life. New York:Double day Anchor Books
} 


\section{Tinjauan Pustaka}

\section{Covid 19}

Coronavirus Disease 19 atau Covid-19 adalah penyakit yang disebabkan oleh virus dan pertama kali muncul di Wuhan, China di akhir tahun 2019. Penyebaran virus Covid-19 begitu cepat, membuat jumlah orang yang terinfeksi terus bertambah tidak hanya di negara China namun menyebar ke seluruh dunia. Di Indonesia, kasus pertama positif Covid-19 resmi diumumkan pemerintah pada awal bulan Maret 2020. Sejak saat itu, semua informasi terkait pandemi akibat virus Covid-19 menjadi pusat perhatian. Informasi yang dicermati beragam, mulai dari pembaharuan data korban yang positif, perkembangan teknik pengobatan, hingga pengaruh dampak sosial dan ekonomi bagi masyarakat selama pandemi. Mengantisipasi penyebaran penularan, pemerintah mengambil langkah preventif yakni penerapan protokol kesehatan.

Gugus Tugas Percepatan Penanganan Covid-19 yang dibentuk pemerintah mengkoordinasikan kegiatan protokol kesehatan antar lembaga pusat dan melakukan sosialisasi pelaksanaan Kenormalan Baru (New Normal) untuk dijalankan masyarakat selama pandemi. Ketua Tim Pakar Gugus Tugas Percepatan Penanganan Covid-19, Wiku Adisasmito mengatakan bahwa New Normal adalah perubahan aktifitas masyarakat agar dapat menjalankan aktivitas normal di saat pandemi namun dilakukan dengan mengedepankan protokol kesehatan sehingga bisa mencegah penyebaran virus. ${ }^{12}$ Implementasinya diatur dalam Pembatasan Sosial Berskala Besar (PSBB) yang keputusannya dikeluarkan oleh Kementerian Kesehatan melalui Peraturan Menteri Kesehatan Nomor 9 tahun 2020, yang merupakan turunan dari Peraturan Pemerintah no 21 tahun 2020 tentang Pembatasan Sosial Berskala Besar (PSBB). Dalam permenkes disebutkan, PSBB adalah pembatasan kegiatan tertentu oleh penduduk pada daerah yang diduga terinfeksi Covid 19 yang disesuaikan agar dapat mencegah penyebaran Covid $19 .{ }^{13}$ Dalam pasal 13 ayat 1 peraturan ini juga disebutkan adanya libur di sekolah dan tempat kerja. Maksud dengan peliburan sekolah pada aturan ini adalah proses belajar mengajar di sekolah ditiadakan dan diganti dengan proses belajar mengajar di rumah yang difasilitasi media belajar yang paling efektif dal $\mathrm{m}$ hal ini adalah pembelajaran elektronik atau e-learning.

\section{Electronic Learning atau E-Learning di masa Pandemi}

Bentuk paling awal dari pendidikan elektronik ditemukan pada pertengahan 1970-an oleh para akademisi yang terlibat sebagai peneliti Arpanet yang merupakan proyek yang menjadi cikal bakal internet. Mereka menggunakan inovasi untuk berkomunikasi dengan mahasiswa melalui email atau surat elektronik. Eksperimen

\footnotetext{
12 https:/www.kompas.com/tren/read/2020/05/27/193200965/infografik--panduan-protokolkesehatan-pencegahan-covid-19-untuk-sambut-new

13 https://www.cnbcindonesia.com/tech/20200326062042-37-147501/para-siswa-ini-5-instruksimendikbud-nadiem-soal-sekolah
} 
pendidikan dan minat siswa dalam teknologi komunikasi baru ini memicu eksplorasi, dan sebagai hasilnya, komunikasi melalui komputer (CMC) tidak hanya menjadi konten saja tetapi juga proses pedagogis. Siswa mulai menggunakan email mengirim pertanyaan kepada profesor dan berkomentar satu sama lain. Pihak kampus mengeksplorasi aplikasi email untuk memberikan informasi tambahan kepada siswa, mengklarifikasi pertanyaan dan memperluas peluang untuk diskusi kelompok yang tidak tergantung waktu dan tempat dalam kursus mereka. Di tahun 1993 bersamaan dengan diperkenalkannya World Wide Web (www) pengguna internet semakin mudah untuk terhubung di hampir semua tempat di dunia. Bentuknya tidak lagi teks namun ditambahkan grafik Pada tahun 1995 WWW mulai diaplikasikan untuk pembelajaran online oleh Universitas di Amerika Serikat dan tahun 1996 dilakukan uji coba terhadap pendidikan berbasis online dengan peserta berskala besar. Tahun 1997 menjadi titik awal web dalam penggunaannya bersama internet digunakan oleh industri dan tahun 2004 dimulai era pembelajaran online secara umum seperti yang kita kenal saat ini. ${ }^{14}$

Implikasi dari teknologi Internet dan Web untuk pendidikan terus berlangsung untuk memanfaatkan dan meningkatkan manfaat pembelajaran online untuk memanfaatkan revolusi teknologi besar ini mempengaruhi pendidikan dan mengubah disiplin kita, dari perubahan terkecil hingga yang paling dramatis. E-learning adalah pembelajaran dengan menggunakan perangkat elektronik, seperti Handphone, Komputer, DVD, Radio, TV dan perangkat elektronik lainnya. Online learning adalah bagian dari E-Learning namun pada penerapannya membutuhkan jaringan internet untuk digunakan pada media elektronik seperti Handphone dan Komputer. ${ }^{15}$

Melalui e-learning, proses belajar mengajar tidak hanya terjadi di ruang kelas tetapi juga di kelas virtual tempat guru dan peserta didik bertemu meski tidak secara fisik. Dalam situasi pandemi yang menganjurkan setiap individu untuk mengurangi kontak fisik, pembelajaran e-learning menjadi solusi. Sayangnya menurut Wakil presiden Ma'ruf Amin, saat ini baru ada 20 dari 4.741 perguruan tinggi di Indonesia yang menerapkan e-learning. ${ }^{16}$ Menurut Wakil Presiden, dengan metode pembelajaran $e$ learning mahasiswa dan pengajar harus melakukan penyesuaian. Karena tidak ada proses tatap muka langsung, sistem belajar jarak jauh ini bisa membuat pelajar tidak disiplin pada saat proses belajar dilakukan. Para pengajar dan mahasiswa harus memiliki kreativitas tinggi agar bisa beradaotasi dengan sistem ini agar proses pemberian dan penyerapan materi bisa berjalan sesuai harapan. Penggunaan dan implementasi e-learning di pendidikan formal tidak mudah, karena merubah paradigma belajar mengajar yang juga harus dilakukan perubahan organisasi, infrastruktur, sumber dana, dan sumber daya manusia. ${ }^{17}$ Seharusnya secara teknis metode pembelajaran E-learning di pendidikan tinggi bukan lagi masalah, karena survei Asosiasi Routledge

14 Harasim, Linda (2012) Learning Theory and Online Technologies New York \& London:

${ }^{15}$ Prawiradilaga DS (2013). Mozaik Teknologi Pendidikan E-Learning Jakarta:Prenada Media

16 https:/www.cnnindonesia.com/nasional/20200923001725-20-549651/maruf-amin-baru-20-dari4741-kampus-terapkan-e-learning

17 Damayanti, Tri et al (2007) E-Learning Pada Pendidikan Jarak Jauh: Konsep yang Mengubah Metode Pembelajaran di Perguruan Tinggi di Indonesia Jakarta: Jurnal Pendidikan Terbuka dan Jarak Jauh, Volume 8, Nomor 2,September 2007 
Penyelenggara Jasa Internet Indonesia (APJII) pada pertengahan tahun 2020 mendapati, pengguna internet Indonesia tercatat 196,7 juta orang. Jumlah ini sebesar atau 73,7 persen dari jumlah keseluruhan penduduk Indonesia sebesar 266,9 juta berdasarkan data BPS. ${ }^{18}$ Namun kemampuan finansial mahasiswa yang beragam, membuat tidak semua mahasiswa memiliki kemampuan untuk memiliki jaringan wifi dan pulsa unlimited atau tak terhingga. Pelaksana tugas Direktur Jenderal Pendidikan Tinggi (Dikti) Kementerian Pendidikan dan Kebudayaan (Kemendikbud) Prof Nizam mendorong perguruan tinggi memberikan kemudahan kepada mahasiswa dan dosen ketika berlangsung pembelajaran jarak jauh, salah satunya dengan pemberian pulsa. Dalam proses belajar jarak jauh, masukan dan aspirasi mahasiswa menjadi salah satu yang harus dipertimbangkan agar pada pengajar dapat dengan cermat menyusun pola belajar, yang pada akhirnya menuingkatkan kemampuan belajar siswa, sehingga penyampaian dan penguasaan materi berlangsung dengan efektif dan lancar. ${ }^{19}$

\section{Computer-Mediated Communication (CMC) dan Hyperpersonal}

Metode Computer-Mediated Communication yang disingkat CMC pertama kali diciptakan dan diperkenalkan oleh Hiltz dan Turoff di tahun 1978 saat keduanya mencoba melakukan komunikasi melalui komputer di Internet. CMC menjadi media untuk membuat, memahami, mentransmisikan, decoding, dan encoding. ${ }^{20}$ Komunikasi yang dimediasi komputer ini meliputi fasilitasi desain dan pengiriman informasi, serta interaksi manusia dengan manusia dan manusia dengan mesin termasuk berbagai implikasi hubungannya. Dalam arti luas, CMC dapat berupa segala bentuk komunikasi yang dimediasi oleh teknologi digital. ${ }^{21}$ Secara teknis CMC telah ada sejak komputer digital elektronik pertama kali ditemukan di era perang dunia II atau setidaknya sejak pertukaran email prototipe pertama di awal tahun 1960. Aspek lain terungkap saat CMC dipersepsikan sebagai proses komunikasi, yang meliputi pesan, pengirim, dan penerima. Oleh karena itu faktor manusia dengan latar belakang sosio kultural, sejarah, dan pedagogisnya berperan penting. ${ }^{22}$ Jika dikaitkan dengan e-learning menjadi hal konvensional untuk membagi CMC dalam dua model, yakni Synchronous Computer Mediated Communication (SCMC) yakni Komunikasi yang dimediasi komputer sinkron, di mana orang berkomunikasi dalam waktu nyata melalui obrolan atau perangkat lunak diskusi, dengan semua peserta di komputer mereka pada waktu yang sama. Dan yang lain adalah Asynchronous Computer Mediated Communication (ACMC) dimana orang berkomunikasi melalui komputer dalam waktu yang tertunda, misal: melalui email..23

18 https://kumparan.com/kumparantech/jumlah-pengguna-internet-indonesia-tahun-2020-capai196-7-juta-naik-karena-wfh-1uYnJ729dTL

19 https://www.merdeka.com/peristiwa/kemendikbud-minta-kampus-bantu-pulsa-mahasiswadan-dosen-selama-kuliah-online.html

20 Hossaini, Seyed Behrouz. (2015). Computer-Mediated Communication: Pedagogical and Language Learning Implications Iran:International Journal on New Trends in Education and Their Implication

${ }^{21}$ Littlejohn, Stephen W. \& Foss, Karen A. (2009). Encyclopedia of Communication Theory. California: SAGE Publications, Inc.

22 Thurlow, Crispin, et al. (2004) Computer Mediated Communication: Social Interaction and the Internet London: Sage Publication

${ }^{23}$ Hossaini. (2015). Op.Cit. 
Melalui SCMC, peserta didik bisa berkomunikasi langsung, cepat berbagi ide selama interaksi, dan harus selalu siap dalam dinamika kelas yang berlangsung online. Sebaliknya ACMC, peserta didik memiliki kesempatan untuk lebih merefleksikan isi dari apa yang akan mereka sampaikan secara fokus dan terarah.

Konsep inti CMC ada tiga yakni, Konsep Komunikasi, Konsep Mediasi dan Komputer. Konsep komunikasi yakni: komunikasi bersifat dinamis, transaksional, multifungsi dan multi modal. Sementara Konsep mediasi meliputi: psikologis, sosial dan kultural. Sementara Komputer: saat ini hampir semua orang memiliki komputer dan melibatkannya dalam berbagai aktivitas. Pada awalnya komunikasi dimediasi komputer dilakukan individu untuk peningkatan status dan kesenangan, mencari pertemanan dan mencari inspirasi. Dalam perkembangannya menarik untuk diteliti bahwa CMC bisa digunakan untuk melihat dinamika interpersonal dalam pengguna komputer khususnya di masa pandemi dimana sosialisasi tanpa batasan bisa dilakukan melalui internet yang saat ini menjadi tempat 'berkumpul' dan mencari teman. Dengan kondisi ini dinamika interpersonal menjadi hyper-personal karena pengguna sangat ini memperoleh impresi online dari individu lain.

Model Hyperpersonal adalah komunikasi yang dibangun melalui CMC dapat menyamai atau bahkan lebih intim dari komunikasi yang dicapai melalui tatap muka. ${ }^{24}$ Konsep ini digambarkan melalui interaksi pengirim pesan dalam upaya melakukan presentasi diri. Ada empat langkah proses komunikasi agar CMC dapat mempengaruhi proses kognitif dan komunikasi yang berkaitan dengan konstruksi dan penerimaan pesan: Pertama, efek dari proses penerima, kedua, efek di antara pengirim pesan, ketiga, atribut saluran, dan keempat, efek umpan balik.

Model Hyperpersonal secara online sejalan dengan Teori Manajemen Kesan yang dipelopori Erving Goffman.25 Menurut Goffman pada saat individu saling berkomunikasi, saat itu pula impresi ingin ditampilkan dan ditujukan pada lawan bicara untuk menunjukan diri mereka. Inilah yang disebut sebagai manajemen kesan (impression management), yaitu bagaimana cara dilakukan agar kesan tertentu bisa muncul mewakili impresi diri untuk mencapai tujuan tertentu. Menurut Goffman, kita menghabiskan sebagian besar waktu untuk melakukan manajemen kesan dan berupaya mempengaruhi orang lain. Ini dilakukan sebagai landasan berhubungan dengan orang lain. ${ }^{26}$ Jika ini berjalan, maka CMC yang tampak dingin karena kurangnya isyarat nonverbal dan sosial, mulai 'hangat' karena model Hyperpersonal melalui CMC mengganti isyarat lain dan membaca isyarat yang ada dengan lebih cermat. ${ }^{27}$

\section{B. METODE PENELITIAN}

Penelitian dilakukan dengan pendekatan kualitatif dengan metode studi kasus eksploratif yang sifatnya fleksibel, terbuka, dan kreatif. Semua pendapat responden McGrew Hill

${ }^{24}$ Griffin, E. (2012). In A First Look At Communication Theory (p. eight edition). Amerika:

25 Thurlow, Crispin, et al. (2004). Op.Cit.

${ }^{26}$ Goffman, Erving (1969). Op.Cit.

${ }^{27}$ Thurlow, Crispin, et al. (2004). Op.Cit. 
wawancara dianggap penting sebagai sumber informasi adanya kelebihan dan kendala pembelajaran e-learning di perguruan tinggi pada saat Pandemi Covid 19. Pengumpulan data primer dilakukan dengan wawancara secara mendalam terhadap 4 orang Mahasiswa Perguruan Tinggi di Jakarta pada jenjang pendidikan Strata 1 dan Strata 2. Untuk menjaga kerahasiaan tidak ada data individu dalam wawancara ini. Pertanyaan dikembangkan dari pendalaman konsep yang tidak muncul atau belum diteliti dalam jurnal terdahulu. Hasil wawancara dikembangkan dan disesuaikan dengan teori terkait dan pengolahan datanya dengan transkrip, mengkoding terbuka, aksial dan selektif. Teknik analisa data dilakukan secara tematik atau naratif, disusul teknik konfirmasi data dengan triangulasi antara: mahasiswa sebagai pelaku, mahasiswa sebagai penerima dan dosen. Wawancara dilakukan terhadap 2 dosen Perguruan Tinggi di Jakarta. Penelitian ini hakikatnya merupakan pendekatan multi metode. Ide dasarnya adalah bahwa fenomena yang diteliti dapat dipahami dengan baik sehingga diperoleh varian informasi yang otentik dari berbagai sudut pandang.

\section{HASIL TEMUAN DAN PEMBAHASAN}

\section{Hasil Temuan}

Berdasarkan hasil wawancara kepada 4 narasumber Mahasiswa, didapatkan temuan menarik tentang adanya interaksi hyperpersonal dan manajemen kesan yang dilakukan oleh setiap narasumber selama proses perkuliahan online. Setiap narasumber memiliki cara yang unik dan berbeda dalam menampilkan dirinya kepada teman dan juga dosen selama perkuliahan online berlangsung. Untuk lebih jelas melihat karakteristik setiap narasumber, dapat melihat hasil wawancara berikut.

P : Peneliti

AS : Mahasiswa sarjana sebuah Perguruan Tinggi di Bandung

JS : Mahasiswi sarjana sebuah Perguruan Tinggi di Malang

IG : Mahasiswa pascasarjana sebuah Perguruan Tinggi di Jakarta

RK : Mahasiswi pascasarjana sebuah Perguruan Tinggi di Jakarta

P : Apakah saudara memiliki kendala dalam teknis perkuliahan jarak jauh dengan memanfaatkan internet?

AS : Saya tidak merasa mengalami kendala teknis yang berarti dalam perkuliahan jarak jauh.

JS : Saya tidak memiliki kendala teknis selama perkuliahan jarak jauh dengan memanfaatkan internet.

IG : Ada kendala teknis yang pernah terjadi saat saya menjalani perkuliahan jarak jauh dengan internet. Misalnya, gangguan sinyal internet saat cuaca buruk.

RK : Kendala teknis yang dapat terjadi saat perkuliahan adalah gangguan sinyal internet dan device (alat) yang bermasalah. 
P : Apakah saudara dapat menerima materi perkuliahan seperti yang diharapkan?

AS : Saya merasa tidak ada permasalahan dalam menerima materi selama perkuliahan online.

JS : Saya dapat menerima materi perkuliahan dengan baik selama ini.

IG : Saya dapat menangkap materi perkuliahan yang disajikan oleh dosen meskipun tidak optimal sebagaimana tatap muka secara langsung. Namun, saya terbantu dengan adanya power point (PPT) yang dikirimkan dosen sebagai materi kuliah.

RK : Saya tidak merasakan masalah yang berarti dalam menangkap materi perkuliahan yang disampaikan oleh dosen dan saya masih dapat memahami materi dengan baik.

P : Dalam perkuliahan online, apakah perlu menunjukkan pada kelas bahwa saudara hadir dalam perkuliahan? Bagaimana caranya?

AS : Perlu, yaitu dengan menunjukkan kehadiran saat presensi perkuliahan. Namun, saya tidak suka bertanya dalam kelas dan hanya mengamati diskusi kelas yang berlangsung.

JS : Perlu. Sesekali saya berpendapat di dalam kelas atau memberikan jawaban saat ditanya oleh dosen.

IG : Saya kira itu perlu. Biasanya saat awal perkuliahan saya menyalakan video dan menjawab pertanyaan dosen bila ditanya.

RK : Saya rasa itu hal yang perlu. Cara yang biasanya saya lakukan adalah dengan menyalakan video sepanjang perkuliahan, memberikan pendapat secara alami mengikuti ritme kelas, dan aktif menanyakan hal-hal yang kurang jelas bagi saya.

P : Dalam perkuliahan online apakah saudara menggunakan variasi background video secara khusus untuk dapat membentuk kesan diri tertentu dalam kelas? Kenapa saudara memilih hal tersebut?

AS : Dalam perkuliahan saya biasanya tidak menggunakan background video karena tidak ingin terlihat menonjol dalam kelas. Namun dalam diskusi kelompok dengan teman, saya lebih santai dan menggunakan background yang lucu dan unik.

JS : Dalam kelas biasanya saya bisa menggunakan atau tidak menggunakan background video yang polos atau tanpa background untuk memberikan kesan serius menyimak.

IG : Background yang biasanya saya gunakan untuk video adalah foto gapura selamat datang di Jawa Timur. Kenapa? Karena saya orang Jawa Timur. Sebetulnya agar video lebih bervariasi sekaligus menutupi apa yang sesungguhnya ada di belakang layar.

RK : Saya tidak menggunakan variasi background saat menyalakan video. Saya lebih suka terlihat natural sedang berada dimana tanpa perlu ribet mengganti background video. 
P : Kesan diri apa yang ingin saudara tunjukkan kepada dosen dan teman saat perkuliahan online?

AS : Kepada dosen menunjukkan kesan serius, sedangkan pada teman menunjukkan kesan pribadi yang asik.

JS : Kalau ke dosen menunjukkan kesan serius menyimak materi. Kalau ke teman menunjukkan kesan tanggap dan asik dalam komunikasi.

IG : Saat di kelas menunjukkan kesan serius dan mengikuti materi dosen dengan baik. Kepada teman lebih cenderung menunjukkan kesan santai.

RK : Saat perkuliahan saya cenderung menunjukkan kesan serius dan turut berpartisipasi aktif dengan bertanya dan memberikan tanggapan dalam kelas. Kepada teman lebih menunjukkan kesan aktif dalam berdiskusi dan mengerjakan tugas kelompok.

P : Apakah upaya menampilkan kesan juga bisa dilakukan dalam kuliah asynchronic? Bagaimana caranya?

AS : Kalau kuliah tidak langsung enaknya tulisan untuk dosen bisa dipersiapkan sebaikbaiknya dan tepat waktu mengumpulkan. Kalau ke teman biasanya dalam chat kelompok diskusi bisa sambil bercanda.

JS : Asynchronic bisa lebih santai dan bisa dibayangkan reaksi dosen ketika membaca tulisan kita. Dibuat yang bagus. Kalau ke teman ingin menunjukkan kita bertanggung jawab dan sering up-date tugas di chat dengan bahasa santai.

IG : Kuliah melalui teks feedback lebih lama dari pada synchronic, harus dimanfaatkan dengan banyak referensi agar hasilnya baik dan dosen memberikan nilai tambah. Kepada teman model asynchronic bisa saling mengirimkan materi bacaan sebagai referensi.

RK : Asynchronic bagi saya bisa jadi nilai tambah karena point yang ingin disampaikan bisa lebih terstruktur dibanding kuliah synchronic. Kepada teman model asynchronic lebih untuk saling mengingatkan dalam pengerjaan tugas.

P : Teman tugas atau diskusi kelompok yang seperti apa yang anda inginkan dalam pembelajaran jarak jauh saat ini?

AS : Teman yang responsif kalau ditanya, tanggung jawab dalam pengerjaan tugas.

JS : Teman yang rajin, yang bisa saling mengingatkan yang bisa diajak diskusi dan mendengar masukan.

IG : Teman yang enak untuk berdiskusi, bertukar referensi.

RK : Yang aktif, bisa memberikan masukan-masukan dan saling mengingatkan.

$\mathrm{P} \quad$ : Apakah teman yang menyenangkan berpengaruh terhadap tugas atau diskusi kelompok? 
AS : Tidak pengaruh terhadap hasil, tapi memberi suasana pada proses. Proses menentukan hasil. Kalau asik diskusi maka hasil akan bagus.

JS : Tidak terlalu pengaruh. Tapi teman-teman menyenangkan membuat kita jadi semangat mengerjakan tugas.

IG : Berpengaruh dalam pengerjaan tugas dan diskusi. Pastinya akan lebih terasa menyenangkan

RK : Buat saya yang penting adalah tanggung jawab. Menyenangkan jadi nilai tambah.

P : Bagaimana pendapat anda terhadap mahasiswa yang senang menggunakan fitur-fitur dalam aplikasi pembelajaran jarak jauh seperti background virtual?

AS : Seru. Ini bedanya kuliah jarak jauh dan tatap muka. Nuansa bisa dihadirkan dengan background yang ditampilkan.

JS : Buat saya biasa saja. Tapi biasanya jadi bisa melihat karakter dan suasana hati teman dari background virtualnya

IG : Menyenangkan. Semacam identitas diri, karena saya juga melakukannya

RK : Menjadi pembeda dalam kuliah jarak jauh. Awalnya untuk menutupi background asli yang mungkin kurang layak ditampilkan, tetapi jadi identitas. Karena teman-teman jadi menunggu-nunggu background apa lagi yang akan dipakai.

P : Apakah sudah sama pengerjaan tugas atau diskusi kelompok jarak jauh dibanding dengan tatap muka?

AS : Sama saja. Kualifikasi teman kelompok yang diharapkan, proses pengerjaan dan koordinasi bisa melalui komputer.

JS : Sama. Beda cara koordinasinya saja. Dulu bisa dikerjakan berkumpul langsung, sekarang berkumpul melalui aplikasi conference.

IG : Tidak ada bedanya. Hanya tidak bertemu secara fisik.

RK : Sama saja. Hanya berbeda cara kita berkomunikasi dan berkoordinasi.

Hasil wawancara Mahasiswa juga kami konfirmasi kepada Dosen pengajar sebagai berikut:

P : Peneliti

HH : Dosen sebuah Perguruan Tinggi di Jakarta

BS : Dosen sebuah Perguruan Tinggi di Jakarta

P : Apakah mahasiswa saat ini sudah mampu mengikuti perkuliahan jarak jauh dengan baik? Apakah masih ada kendala? 
$\mathrm{HH}$ : Sebagian besar sudah bisa mengikuti kuliah jarak jauh, sudah bisa mengatasi kendala teknis dan bisa menyerap pembelajaran yang disampaikan.

BS : Kondisi perkuliahan jarak jauh saat ini sudah semakin baik. Mahasiswa sudah mengantisipasi dan mengatasi masalah teknis yang pada awalnya menjadi kendala utama. Artinya materi kuliah juga sudah semakin bisa diserap dengan baik.

P : Mahasiswa dalam mengikuti kuliah Jarak Jauh ingin mendapatkan kesan hadir dan serius dalam perkuliahan seperti halnya dalam kuliah tatap muka. Apakah bisa tertangkap oleh anda dalam kuliah Synchronic maupun Asynchronic saat ini?

$\mathrm{HH}$ : Untuk kuliah Synchronic lebih mudah menilai kehadiran dan kesan yang ingin ditampilkan mahasiswa. Apakah mereka disiplin hadir sejak awal kuliah dimulai. Kemudian apakah mereka menghidupkan video, Bagi saya yang hidupkan video dari awal lebih baik dari pada yang mematikan video. Tapi ada yang beralasan kendala jaringan. Kemudian apakah mereka terlibat aktif bertanya dan berdiskusi, saya lihat juga bagaimana etika bertanya. Dari sini saya bisa melakukan penilaian partisipasi yang menjadi nilai tambah dalam penilaian akhir. Untuk Asynchronic, karena berupa teks kita lihat bagaimana struktur dan poin penulisan. Ada yang tulisan panjang tapi tidak ada isinya. Yang pasti pengumpulan tugas harus sesuai tanggal yang disepakati.

BS : Indikator mahasiswa yang serius hadir dalam perkuliahan bisa dilihat dari kehadiran, sama seperti kuliah tatap muka dulu. Kalau dulu hadir di kelas maka akan hadir sampai perkuliahan selesai, tapi sekarang karena secara fisik tidak bertemu mahasiswa tidak konsisten berada di depan komputer dan mematikan video. Memang hasil akhir tetap pada nilai ujian, apakah mereka mampu menyerap dan memperkaya materi yang disampaikan.

P : Bagaimana dengan penggunaan artificial background video selama perkuliahan. Apakah ada kesan tersendiri bagi pengajar? Lalu bagaimana jika mereka membuka diskusi dalam chat?

HH : Buat saya tidak masalah dan tidak berpengaruh, sepanjang backdrop yang digunakan wajar. Untuk diskusi sebaiknya di aplikasi diskusi kelas jika terkait pelajaran secara umum, sehingga saya tidak perlu menjelaskan berulang. Chat personal digunakan untuk pertanyaan seputar perkuliahan tetapi lebih pribadi. Cara mereka bertanya bisa menimbulkan kesan kepada pengajar, mereka kritis dan fokus sekaligus evaluasi kepada saya selaku dosen apakah materi yang saya sampaikan cukup jelas atau tidak.

BS : Ini menjadi pembeda kuliah online. Biarkan ini jadi warna dalam kelas. Saya tidak masalah asal gambar yang ditampilkan tidak mengganggu suasana perkuliahan.

P : Jika memang kendala teknis dan materi perkuliahan sudah tidak ada, apakah ada hal lain yang masih kurang dalam pengajaran jarak jauh ini dibanding pengajaran tatap muka?

HH : Menangkap ekspresi siswa. Mudah-mudahan ada aplikasi yang langsung membuat muka siswa terlihat jelas ketika bertanya. Bagi saya ekspresi itu penting, seperti biasa saya bisa lihat dalam kuliah tatap muka. Saya ingin melihat ekspresi mereka ketika bertanya. Aplikasi yang saat ini digunakan muka mereka kecil-kecil. Selain itu, ketika mereka 
kumpulkan tugas praktikum kemampuan mereka membuat video menjadi kendala untuk melihat apakah proses sudah dilakukan sesuai tutorial. Selain itu bau dan suara proses praktik tidak bisa tertangkap kamera.

BS : Memang tidak sepenuhnya sama kuliah jarak jauh dan tatap muka langsung. Tetap ada sekat. Meskipun online respon mahasiswa kepada dosen atau sebaliknya, maupun mahasiswa kepada mahasiswa atau sebaliknya tidak sama seperti spontan dalam perkuliahan tatap muka.

\section{Pembahasan}

Selama proses perkuliahan di tengah pandemi, sebagian besar Perguruan Tinggi di Indonesia memanfaatkan media online dan perangkat komputer dalam menjalankan proses pengajaran. Komunikasi yang termediasi oleh komputer dan segala perangkat elektronik yang dapat menghubungkan individu satu dengan yang lain disebut dengan Computer-Mediated Communication (CMC). Komunikasi yang termediasi oleh komputer ini membawa sedikit-banyak perubahan dalam proses interaksi perkuliahan yang terjadi dibandingkan saat tatap muka secara langsung.

Studi lebih lanjut pada CMC berusaha untuk melihat pola interaksi user dan bagaimana interaksi tersebut terjadi. Pola interaksi yang terjadi pada CMC dikembangkan menjadi tiga pola yaitu : impersonal, interpersonal, dan hyperpersonal. Pola komunikasi impersonal terjadi bila interaksi yang terjalin bagaikan komunikasi satu arah dengan menurunnya hubungan sosial yang terjalin. Hal ini bisa disebabkan karena tidak adanya komunikasi nonverbal yang menambah suasana pada pesan yang disampaikan. Bila pola komunikasi impersonal fokus pada pentingnya isyarat nonverbal, maka pola komunikasi interpersonal beranggapan bahwa bahasa dan pesan yang disampaikan secara verbal merupakan hal yang utama untuk mengembangkan hubungan interpersonal. ${ }^{28}$ Dua pola ini berbeda dengan pola komunikasi hyperpersonal yang terjadi dalam CMC. Pada komunikasi hyperpersonal, pengirim pesan CMC dapat menunjukkan diri sendiri lebih selektif, dengan menyembunyikan penampilan fisik ataupun identitas dirinya. CMC memungkinkan pengguna komputer untuk menampilkan, menyeleksi, memilah informasi, dan isyarat yang ditransmisikan ke penerima. Sehingga, komunikator pada CMC dapat lebih berhati-hati dalam menampilkan diri.

Hyperpersonal adalah pola komunikasi yang dibangun melalui CMC yang dapat menyamai atau bahkan lebih nyaman dari komunikasi yang dicapai melalui tatap muka. ${ }^{29}$ Konsep ini digambarkan melalui interaksi pengirim pesan dalam upaya melakukan presentasi diri dengan cara yang lebih disukai. Pola inilah yang juga dapat terjadi dalam interaksi mahasiswa dan dosen selama menjalani perkuliahan berbasis media online.

28 Walther, JB (1996). Computer-Mediated Communication: Impersonal, Interpersonal and Hyperpersonal Interaction. SAGE Publication

${ }^{29}$ Griffin, E. (2012). In A First Look At Communication Theory (p. eight edition). Amerika: McGrew Hill 
Berdasarkan hasil wawancara diatas, dapat diamati bahwa masing-masing individu mahasiswa memiliki cara masing-masing dalam menampilkan citra diri di dalam forum kelas secara online. Ada individu yang merasa nyaman untuk tidak tampil menonjol dalam kelas. Ada pula individu yang merasa nyaman untuk aktif berpartisipasi dalam diskusi materi saat perkuliahan online.

Dalam perkuliahan online, terdapat beberapa kendala teknis yang dapat terjadi. Kendala teknis yang biasanya dapat terjadi berkaitan dengan gangguan jaringan internet dan juga kendala peralatan elektronik yang digunakan. Namun, meski terdapat kendala teknis seperti gangguan jaringan internet dan juga peralatan elektronik yang digunakan, pesan dan materi yang disampaikan oleh dosen tetap dapat ditangkap oleh mahasiswa. Mahasiswa juga dapat lebih memahami perkuliahan dengan adanya materi kuliah yang dikirimkan oleh dosen sebagai bahan ajar.

Menunjukkan keberadaan diri dalam ruang kelas merupakan hal yang penting. Terutama dalam urusan presensi kehadiran kuliah. Cara yang dapat dilakukan oleh masing-masing mahasiswa pun berbeda. Ada yang lebih memilih diam dan menjadi pendengar, namun saat ditanya tetap dapat menjawab pertanyaan yang diajukan oleh dosen. Ada mahasiswa yang menyalakan video hanya di awal perkuliahan lalu selanjutnya mematikan video. Ada pula yang mengikuti kelas dengan menyalakan video dari awal hingga akhir perkuliahan, serta menjadi mahasiswa yang aktif memberikan pendapat dalam ruang kelas.

Dalam proses perkuliahan setiap mahasiswa melakukan manajemen kesan yang ditampilkan di dalam forum. Secara umum, mahasiswa berusaha menampilkan kesan yang serius dan memperhatikan materi perkuliahan yang disampaikan dosen dengan baik. Kesan serius dan memperhatikan materi dengan baik ini ditunjukkan dengan mengatur background video dengan gambar yang cenderung polos atau gambargambar yang tidak mengundang tawa bagi yang melihat. Gambar-gambar yang dipilih sebagai background video merupakan bagian dari representasi diri mahasiswa yang dirasa nyaman untuk ditunjukkan dalam forum perkuliahan. Selanjutnya manajemen kesan serius dan menyimak juga dilakukan dengan aktif berpartisipasi dalam diskusi kelas dengan menggunakan bahasa yang formal. Manajemen kesan yang ditunjukkan pada dosen berbeda dengan apa yang biasanya ditunjukkan kepada teman sesama mahasiswa. Bila tidak ada dosen, mahasiswa lebih cenderung menunjukkan kesan yang lebih santai dan pembawaan diri yang asik.

Ada perbedaan untuk mahasiswa jenjang S1 dan S2. Pada jenjang S1 kesan asik dan menyenangkan yang ingin didapat mahasiswa dalam lingkup pertemanan maupun dalam tugas kelompok lebih besar. Asik dan menyenangkan biasanya dilakukan dengan obrolan dan menggunakan background video yang lucu saat kamera sedang menyala. Namun di jenjang S2, kesan yang ingin ditampilkan kepada teman kuliah lebih kepada yang bersangkutan adalah pribadi yang enak untuk diajak diskusi dan bertanggung jawab terhadap tugas kelompok.

Untuk kuliah asynchronic, kesan yang ingin ditampilkan dilakukan dengan penggunaan teks. Untuk dosen tulisan dibuat lebih terstruktur sehingga timbul kesan serius dan fokus dalam pengerjaan tugas. Sementara dalam pertemanan, teks bisa 
digunakan untuk membuat pembahasan menjadi santai namun dalam konteks yang sebagai mahasiswa yang bisa diandalkan dalam mengerjakan tugas-tugas kelompok.

Dari wawancara di atas juga terlihat bahwa komputer bisa memediasi tugas kelompok sesama mahasiswa sama halnya seperti dalam diskusi tatap muka sebelum masa Pandemi. Dalam diskusi mahasiswa menginginkan suasana menyenangkan yang bisa dihadirkan oleh teman-teman mereka. Aplikasi virtual background yang digunakan sesama teman bisa membuat cair suasana diskusi yang secara tidak langsung menciptakan isyarat non verbal yang dikirimkan dan ditangkap peserta diskusi atau partisipan dalam kelas. Reaksi teman-teman dalam kelompok bisa menjadi sarana membuat suasana diskusi lebih santai dan lebih intim. Virtual background menjadi pembeda yang tidak ditemukan dalam perkuliahan tatap muka. Meski begitu mahasiswa sepakat, target utama tetap pada batas waktu pengerjaan tugas.

Berdasarkan hasil wawancara dosen, pengaturan kesan yang ingin ditampilkan mahasiswa berhasil ditangkap oleh dosen, bahkan menjadi nilai tambah bagi mahasiswa yang bisa menunjukkan kesan yang kuat dalam menjalani perkuliahan. Dosen sudah memiliki indikator kesan seperti apa yang baik dan perlu dicatat sebagai nilai tambah. Hal ini sejalan dengan kesan yang ingin ditampilkan mahasiswa untuk serius dan fokus dalam pembelajaran. Jika kesan kehadiran dalam perkuliahan tidak kuat, dosen juga menangkap hal yang sama. Dosen juga ingin menciptakan suasana menyenangkan dan memudahkan mahasiswa dalam kelas. Mahasiswa diberikan kebebasan untuk mengatur kesan. Dalam perkuliahan online, Artificial background menjadi pembeda. Para dosen tidak menjadikan hal ini sebagai masalah dan pengganggu proses belajar mengajar, sepanjang yang ditampilkan adalah gambar yang etis dan tidak mengganggu fokus siswa lain. Aplikasi chat yang seharusnya memudahkan komunikasi juga bisa menjadi nilai tambah dalam perkuliahan online. Namun yang harus digaris bawahi adalah, cara bertanya dan penyampaian maksud dalam kolom chat harus sesuai etika dalam pembelajaran. Meski begitu masih ada keterbatasan aplikasi bagi dosen untuk mencermati ekspresi spontan mahasiswa saat berinteraksi pada kelas online. Ekspresi sebagai isyarat non-verbal mempertegas impresi yang akan disampaikan mahasiswa di kelas. Di pihak lain, bagi dosen ekspresi menjadi alat evaluasi apakah perkuliahan sudah berjalan sesuai yang diharapkan dan materi yang disampaikan dipahami oleh mahasiswa.

\section{KESIMPULAN}

Pola komunikasi hyperpersonal yang disandingkan dengan teori Manajemen Impresi berhasil dimanfaatkan oleh mahasiswa dalam perkuliahan yang dimediasi komputer. Meski masih ada beberapa hal yang memerlukan penyempurnaan teknis, impresi atau pesan yang ditampilkan mahasiswa berhasil ditangkap oleh sesama mahasiswa dan dosen, seperti impresi yang dikirimkan dan diterima pada saat kuliah tatap muka berlangsung. Gambaran diri ini dibentuk dengan menyeleksi dan menentukan respon apa yang harus ditampilkan dalam kondisi suasana kelas tertentu melalui aplikasi yang tersedia untuk pembelajaran secara synchronic maupun asynchronic.. Proses membentuk gambaran diri ini kemudian dapat dikatakan sebagai 
bentuk dari manajemen impresi mahasiswa dalam forum perkuliahan online. Kondisi ini akan menjadikan kuliah yang dimediasi komputer yang seolah kaku, ternyata bisa menjadi sarana komunikasi yang menyenangkan, responsif dan hangat layaknya perkuliahan tatap muka.

Di masa mendatang untuk mendapatkan hasil yang lebih komprehensif perlu dilakukan penelitian serupa terhadap mahasiswa dengan menyesuaikan jumlah sebarannya di wilayah Indonesia, karena tantangan pengajaran jarak jauh di setiap daerah pasti berbeda tergantung infrastruktur dan kesiapan SDM di wilayah masingmasing. Protokol pengajaran yang disesuaikan dengan Kenormalan Baru di Masa Pandemi tampaknya belum akan berakhir dalam waktu dekat. Penelitian ini diharapkan bisa menjadi masukan bagi pihak yang terlibat dalam penyelenggaran pendidikan tinggi di tanah air, untuk terus mencari cara agar kualitas pendidikan tinggi dengan metode e-learning semakin mendekati kualitas pada masa tatap muka atau bahkan bisa melampauinya karena adanya bantuan teknologi yang pastinya akan terus dikembangkan menyesuaikan kebutuhan pendidikan terkini.

\section{REFERENSI}

\section{Buku}

Goffman, Erving (1969) The Presentation of Self in Everyday Life New York:Double day Anchor Books

Griffin, E. (2012). In A First Look At Communication Theory (p. eight edition). Amerika: McGrew Hill.

Harasim, Linda (2012) Learning Theory and Online Technologies New York \& London: Routledge

Littlejohn, Stephen W. \& Foss, Karen A. (2009). Encyclopedia of Communication Theory. California: SAGE Publications, Inc.

Thurlow, Crispin et al (2004) Computer Mediated Communication: Social Interaction and the Internet London: Sage Publication

Prawiradilaga DS (2013). Mozaik Teknologi Pendidikan E-Learning Jakarta:Prenada Media

Tsai, Susanna \& Machado, Paulo (2002). E-learning. Online Learning, Web-Based Learning, or distance learning: unveiling the ambiguity in current terminology E-Learning Magazine

\section{Artikel Jurnal}

Damayanti, Tri et al (2007) E-Learning Pada Pendidikan Jarak Jauh: Konsep yang Mengubah Metode Pembelajaran di Perguruan Tinggi di Indonesia Jakarta: Jurnal PendidikanTerbuka dan Jarak Jauh, Volume8, Nomor 2,September2007 
Hossaini, Seyed Behrouz (2015). Computer-Mediated Communcation: Pedagogical and Language Learning Implications Iran:International Journal on New Trends in Education and Their Implication

Hubackova, Sarka (2015). History And Perspectives Of Elearning Procedia - Social and Behavioral Sciences 191, 1187 - 1188

Hsu, Stella \& Beasly, Robert (2019). The Effects of International Email and Skype Interactions on Computer-Mediated Communication Perceptions and Attitudes and Intercultural Competence in Taiwanese Students

Fay, Maggie (2017). Computer-Mediated Developmental Math Courses in Tennessee High Schoolsand Community Colleges:An Exploration of the Consequences of Institutional Context Community College Research Center, USA

Kano, Masayo (2020). Maintaining and Enhancing Students' Collaborative Learning in a Japanese EFL Higher Education Context Japan: JEICOM

Radoli, Lydia Ouma (2020). Switching to SIDE Mode"- COVID-19 and the Adaptation of Computer Mediated Communication Learning in Kenya Kenya:RAIS

Walther, JB (1996). Computer-Mediated Communication: Impersonal, Interpersonal and Hyperpersonal Interaction. SAGE Publication

Zaharah, et al (2020). Impact of Corona Virus Outbreak Towards Teaching and Learning Activities in Indonesia. Salam Jurnal, Jakarta

\section{Artikel koran pada website}

Asmara, Chandra Gian (2020) Para Siswa, Ini 5 Instruksi Mendikbud Nadiem Soal Sekolah. CNBC Indonesia Retrieved from https://www.cnbcindonesia.com/tech/20200326062042-37-147501/para-siswaini-5-instruksi-mendikbud-nadiem-soal-sekolah

CNN Indonesia (2020) Ma'ruf Amin: Baru 20 dari 4.741 Kampus Terapkan e-Learning. https://www.cnnindonesia.com/nasional/20200923001725-20-549651/marufamin-baru-20-dari-4741-kampus-terapkan-e-learning

Tamtomo, Akbar Bayu (27 Mei 2020) Panduan Protokol Kesehatan Pencegahan Covid 19 untuk Sambut New Normal Kompas.com. https://www.kompas.com/tren/read/2020/05/27/193200965/infografik-panduan-protokol-kesehatan-pencegahan-covid-19-untuk-sambut-new

Purnamasari, DM (2020). Wapres: Baru Ada 20 dari 4.741 Perguruan Tinggi yang Terapkan Belajar Daring Kompas.com 22 Septermber 2020 https://nasional.kompas.com/read/2020/09/22/12262611/wapres-baru-ada-20dari-4741-perguruan-tinggi-yang-terapkan-belajar-daring?page=all 
KumparanTech (10 November 2020). Jumlah Pengguna Internet Indonesia Tahun 2020

Capai 196,7 Juta, Naik karena WFH.

https://kumparan.com/kumparantech/jumlah-pengguna-internet-indonesiatahun-2020-capai-196-7-juta-naik-karena-wfh-1uYnJ729dTL

Dedi Rahmadi (6 April 2020) Kemendikbud Minta Kampus Bantu Pulsa Mahasiswa dan Dosen selama Kuliah Online Merdeka.com. https://www.merdeka.com/peristiwa/kemendikbud-minta-kampus-bantupulsa-mahasiswa-dan-dosen-selama-kuliah-online.html

\section{Website}

www.kemendikbud.go.id. Mendikbud Terbitkan SE tentang Pelaksanaan Pendidikan dalam Masa Darurat Covid-19 24 Maret 2020 retrived from https://www.kemdikbud.go.id/main/blog/2020/03/mendikbud-terbitkan-setentang-pelaksanaan-pendidikan-dalam-masa-darurat-covid19 
Atika Suri, Firda Ayu Kusuma Dewi Subagyo, Irwansyah

108 -Fakultas Syariah dan Hukum UIN Syarif Hidayatullah Jakarta 